\title{
Stimulation of $\beta$-Amyloid Precursor Protein Trafficking by Insulin Reduces Intraneuronal $\beta$-Amyloid and Requires Mitogen-Activated Protein Kinase Signaling
}

\author{
Laura Gasparini, ${ }^{1,3,4}$ Gunnar K. Gouras,, ${ }^{1,3}$ Rong Wang, ${ }^{2}$ Rachel S. Gross,, ${ }^{1}$ M. Flint Beal, ${ }^{3}$ Paul Greengard, ${ }^{1}$ \\ and Huaxi $\mathbf{X} \mathbf{u}^{1}$ \\ 1 Laboratory of Molecular and Cellular Neuroscience, Fisher Center for Research on Alzheimer Disease, and 2Laboratory \\ for Mass Spectrometry, The Rockefeller University, New York, New York 10021, '3Department of Neurology and \\ Neuroscience, Weill Medical College of Cornell University, New York, New York 10021, and ${ }^{4}$ Neurobiology Laboratory, \\ IRCCS Centro San Giovanni di Dio-Fatebenefratelli, Brescia, Italy
}

\begin{abstract}
Alzheimer's Disease (AD) is characterized by cerebral accumulation of $\beta$-amyloid peptides $(A \beta)$, which are proteolytically derived from $\beta$-amyloid precursor protein ( $\beta$ APP). $\beta$ APP metabolism is highly regulated via various signal transduction systems, e.g., several serine/threonine kinases and phosphatases. Several growth factors known to act via receptor tyrosine kinases also have been demonstrated to regulate s $\beta A P P$ secretion. Among these receptors, insulin and insulin-like growth factor-1 receptors are highly expressed in brain, especially in hippocampus and cortex. Emerging evidence indicates that insulin has important functions in brain regions involved in learning and memory. Here we present evidence that insulin significantly reduces intracellular accumulation of $A \beta$ and that it does so by accelerating $\beta A P P / A \beta$ trafficking from the trans-
\end{abstract}

Golgi network, a major cellular site for $A \beta$ generation, to the plasma membrane. Furthermore, insulin increases the extracellular level of $A \beta$ both by promoting its secretion and by inhibiting its degradation via insulin-degrading enzyme. The action of insulin on $\beta A P P$ metabolism is mediated via a receptor tyrosine kinase/mitogen-activated protein (MAP) kinase kinase pathway. The results suggest cell biological and signal transduction mechanisms by which insulin modulates $\beta A P P$ and $A \beta$ trafficking in neuronal cultures.

Key words: $\beta$-amyloid; $\beta$-amyloid precursor protein; insulin; MAPK; Alzheimer's disease; diabetes mellitus; intracellular trafficking; endoplasmic reticulum; trans-Golgi network; plasma membrane
Neuropathological hallmarks of Alzheimer's Disease (AD) include deposition of $\beta$-amyloid (A $\beta$ ) plaques, neurofibrillary tangles, and neuronal cell loss in vulnerable brain regions. Plaques contain an aggregated population of heterogeneous $\mathrm{A} \beta$ peptides derived from $\beta$-amyloid precursor protein ( $\beta$ APP). Full-length $\beta$ APP undergoes proteolytic $\beta$-secretase and $\gamma$-secretase activities to generate $\mathrm{A} \beta 40$ and $\mathrm{A} \beta 42$ peptides, the predominant $\mathrm{A} \beta$ variants. In addition to these amyloid-generating activities, fulllength $\beta$ APP can undergo alternative processing by an enzymatic activity termed " $\alpha$-secretase" that cleaves within the $\mathrm{A} \beta$ region. This activity releases a soluble fragment ( $\beta A P P \alpha)$ extracellularly and precludes $A \beta$ formation. Several studies indicate that $\mathrm{A} \beta$ is toxic to neurons. Accumulation of $\mathrm{A} \beta$ peptides within the brain is believed to initiate the pathological cascade culminating

\footnotetext{
Received Sept. 7, 2000; revised Jan. 10, 2001; accepted Jan. 18, 2001.

This work was supported by National Institutes of Health Grant AG09464 to P.G., by the Alzheimer's Association (G.K.G., R.W., and H.X.), by the American Health Assistance Foundation (H.X.), and by the Ellison Medical Foundation (P.G. and H.X.). We are grateful to Dr. R. Roth (Stanford University) for the gift of $28 \mathrm{H} 1$ and 9B12 monoclonal antibodies; Dr. G. Thinakaran (University of Chicago) for providing human $\beta$ APP-transfected N2a cells; Drs. W. Netzer and H. Lin (Rockefeller University) for contributing to the optimization of $\mathrm{A} \beta$ detection techniques; Drs. D. Accili (Columbia University), M. Stoffel (Rockefeller University), and J. Schlessinger (New York University Medical Center) for helpful discussions; and Dr. J. Greenfield (Rockefeller University) for critical reading of this manuscript.

Correspondence should be addressed to Huaxi Xu, Laboratory of Molecular and Cellular Neuroscience, Fisher Center for Research on Alzheimer Disease, The Rockefeller University, 1230 York Avenue, Box 296, New York, NY 10021. E-mail: xuh@rockvax.rockefeller.edu.

Dr. Gasparini's present address: Nicox Research Institute, Milan, Italy. Copyright (C) 2001 Society for Neuroscience $\quad 0270-6474 / 01 / 212561-10 \$ 15.00 / 0$
}

in clinical AD, a hypothesis supported by the development of early-onset familial AD (FAD) within pedigrees harboring autosomal dominant gene mutations in $\beta$ APP that lead to the excessive generation of $\mathrm{A} \beta$ (for review, see Selkoe, 1998). Cell biological studies have demonstrated that both $\mathrm{A} \beta 40$ and $\mathrm{A} \beta 42$ are produced intracellularly (Cook et al., 1997; Xu et al., 1997; Lee et al., 1998; Skovronsky et al., 1998; Greenfield et al., 1999). Moreover, recent evidence raises the possibility that intracellular A $\beta 42$ may play a direct pathogenic role in AD neuropathology (for review, see Wilson et al., 1999; Gouras et al., 2000).

$\beta$ APP metabolism is highly regulated via various signal transduction systems, e.g., various serine/threonine kinases and phosphatases (for review, see Mills and Reiner, 1999). Several growth factors known to act via receptors with intrinsic tyrosine kinase activity also have been demonstrated to regulate $\mathrm{s} \beta \mathrm{APP}$ secretion (Refolo et al., 1989; Schubert et al., 1989). Among these receptors, insulin and insulin-like growth factor-1 (IGF-1) receptors are highly expressed in brain, particularly in hippocampus and cortex (Werther et al., 1987). Recently, it has been demonstrated that insulin receptors are concentrated at the synaptic level and that they are a component of postsynaptic densities in cultured hippocampal neurons (Abbott et al., 1999). Moreover, insulin can recruit $\mathrm{GABA}_{\mathrm{A}}$ receptors to the postsynaptic domain (Wan et al., 1997), suggesting a role for this hormone in synaptic plasticity. Emerging evidence indicates that insulin has important functions in brain regions involved in learning and memory (Wickelgren, 1998; Zhao et al., 1999). Recent findings demonstrated insulin receptor upregulation and reduced insulin receptor-mediated ty- 
rosine kinase activity in AD brains (Frolich et al., 1998, 1999). Insulin and IGF-1 have been shown to regulate tau phosphorylation via GSK-3 $\beta$, suggesting that neurofibrillary tangle formation in AD may be downstream of insulin signaling (Hong and Lee, 1997; Lesort et al., 1999; Lesort and Johnson, 2000). Recently, investigators have begun to address the potential role of insulin in $\beta$ APP metabolism. It was shown that insulin elevates s $\beta$ APP secretion in SH-SY5Y cells (Solano et al., 2000). Moreover, it was demonstrated that insulin-degrading enzyme (IDE) degrades extracellular $\mathrm{A} \beta$ in microglial and neuronal cultures and that insulin can prevent this degradation, thereby impairing the clearance of extracellular A $\beta$ (Qiu et al., 1998; Vekrellis et al., 2000).

Here we report that insulin decreases intracellular levels and increases extracellular levels of both $A \beta 40$ and $A \beta 42$. These effects of insulin are associated with accelerated $\beta \mathrm{APP} / \mathrm{A} \beta$ trafficking from the Golgi/trans-Golgi network (TGN) to the plasma membrane and are prevented by inhibitors of tyrosine kinase and MAP kinase kinase.

\section{MATERIALS AND METHODS}

Cell cultures. N2a neuroblastoma cells transfected with human $\beta$ APP695 were maintained in medium containing 50\% DMEM and 50\% Opti-

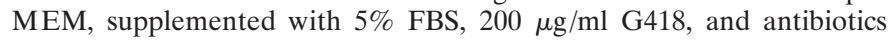
(Life Technologies, Gaithersburg, MD). Primary neuronal cultures were derived from the cerebral cortices of day 17 (E17) embryos obtained from timed pregnant Sprague Dawley rats as described previously (Gouras et al., 1998). Neurons were used for experiments after 4-5 d in culture.

Pulse-chase experiments and insulin treatment. N2a cells $(80 \%$ confluent in $10 \mathrm{~cm}$ dish) or primary neuronal cultures $\left(10^{7}\right.$ cells $/ 10 \mathrm{~cm}$ dish $)$

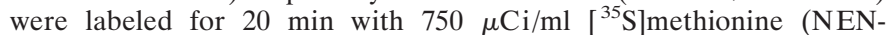
DuPont, Boston, MA) in methionine-free DMEM supplemented with L-glutamine (Life Technologies). Cells were chased at $37^{\circ} \mathrm{C}$ in serum-free DMEM (Life Technologies) or in serum- and glucose-free DMEM supplemented with $50 \mathrm{~mm}$ 2-deoxy-D-glucose in the absence or presence of insulin (Sigma, St. Louis, MO). In some experiments 0.3-30 $\mu \mathrm{M}$ glucagon, 0.1-1 $\mu \mathrm{M}$ IGF-1, 2.5-25 ng/ml EGF, 25-250 ng/ml NGF, 1-10 ng/ml PDGF, 10-100 ng/ml aFGF, or 10-100 ng/ml bFGF (BD Transduction Laboratories, Franklin Lakes, NJ; gifts of Dr. J. Schlessinger, New York University Medical Center) was added during the chase. For continuous metabolic labeling the cells were incubated for $4 \mathrm{hr}$ with 750 $\mu \mathrm{Ci} / \mathrm{ml}\left[{ }^{35} \mathrm{~S}\right]$ methionine in methionine-free DMEM supplemented with L-glutamine in the absence or presence of $1 \mu \mathrm{M}$ insulin. For steady-state experiments the cells were treated for 4-16 hr with $0.3-1 \mu \mathrm{M}$ insulin in the presence or absence of 10-25 $\mu \mathrm{M}$ tyrphostin-25, 500 nM wortmannin, $25 \mu \mathrm{M} \mathrm{U} 73122$, or $10 \mu \mathrm{M}$ PD98059; the samples were analyzed by Western blot.

A $\beta$ degradation assay. N2a cells expressing wild-type human $\beta$ APP 695 were labeled continuously for $4 \mathrm{hr}$ with $750 \mu \mathrm{Ci} / \mathrm{ml}\left[{ }^{35} \mathrm{~S}\right]$ methionine, and medium was collected to serve as the source for labeled $\mathrm{A} \beta$ and $\operatorname{s} \beta \mathrm{APP} \alpha$ proteins. Nonlabeled serum-free conditioned medium (CM) was collected after the incubation of primary neuronal cultures for $16 \mathrm{hr}$. This $\mathrm{CM}$ was mixed with the labeled $\mathrm{A} \beta / \mathrm{s} \beta \mathrm{APP} \alpha$-containing medium and incubated further at $37^{\circ} \mathrm{C}$ for $16 \mathrm{hr}$ in the absence or presence of $1 \mu \mathrm{M}$ insulin and/or $1 \mathrm{~mm}$ 1,10-phenantroline. In some experiments IDE was eliminated from the cold CM by immunodepletion, using an anti-IDE monoclonal antibody (9B12) (Shii and Roth, 1986). The amounts of labeled $\mathrm{A} \beta$ or $\mathrm{s} \beta \mathrm{APP} \alpha$ remaining in each sample after incubation were determined by immunoprecipitation with antibody $4 \mathrm{G} 8$ (for $\mathrm{A} \beta$ ) or $6 \mathrm{E} 10$ (for $\mathrm{s} \beta \mathrm{APP} \alpha)($ Senetek PLC, St. Louis, MO), followed by $10-20 \%$ Tris/tricine $(\mathrm{A} \beta)$ or $4-12 \%$ Tris/glycine $(\mathrm{s} \beta \mathrm{APP} \alpha)$ SDS-PAGE.

Immunoprecipitation and Western analysis. Media were collected, centrifuged briefly to remove cell debris, and sequentially immunoprecipitated first with $4 \mathrm{G} 8$ for $\mathrm{A} \beta$ and then with $6 \mathrm{E} 10$ for $\mathrm{s} \beta \mathrm{APP} \alpha$ secreted from N2a cells or $22 \mathrm{C} 11$ (Roche Pharmaceuticals, Nutley, NJ) for s $\beta$ APP secreted from rat neurons. $\mathrm{s} \beta \mathrm{APP} \beta$ secreted from N2a cells was determined by immunoprecipitation with $22 \mathrm{C} 11$ antibody after immunodepletion of $\mathrm{s} \beta \mathrm{APP} \alpha$ with $6 \mathrm{E} 10$ antibody. Immunoprecipitation of IDE was performed with 28H1 monoclonal antibody (Shii and Roth, 1986). Cells $\left(1-2 \times 10^{7}\right)$ were scraped from plates in ice-cold PBS with a rubber policeman. After centrifugation the pellets were treated with $250 \mu \mathrm{l}$ of 3\% SDS in PBS containing $10 \mu \mathrm{l} / \mathrm{ml}$ of $\beta$-mercaptoethanol and subjected to vortexing and heating at $95^{\circ} \mathrm{C}$ for $10 \mathrm{~min}$, followed by sonication and centrifugation at $100,000 \times g$ for $10 \mathrm{~min}$. The resultant supernatants were diluted 1:4; adjusted to a final concentration of $2 \%$ Triton X-100 and (in mM) $190 \mathrm{NaCl}, 20$ Tris-HCl, pH 8.8, and 2 EDTA; and subjected to immunoprecipitation and SDS-PAGE analysis that used 10-20\% Tris/ tricine gels (for $\mathrm{A} \beta$ ) or $4-12 \%$ Tris/glycine gels (for $\mathrm{s} \beta \mathrm{APP} \alpha$ detection). For Western blot the samples were transferred to polyvinylidene difluoride (PVDF) membranes (Millipore, Bedford, MA or Bio-Rad, Hercules, CA), and the membranes were boiled in PBS for $5 \mathrm{~min}$. A $\beta$ and $\mathrm{s} \beta \mathrm{APP} \alpha$ were detected by using $6 \mathrm{E} 10$ monoclonal antibodies. For Western blot analysis of full-length $\beta$ APP and presenilin-1 (PS-1) N-terminal fragment, the samples were analyzed on $12 \%$ SDS-PAGE gels, transferred to PVDF membrane (Millipore), and immunoblotted with antibody 369 (Buxbaum et al., 1990) and antibody Ab14 (Seeger et al., 1997), respectively. Anti-insulin receptor antibody was from Neomarkers (Fremont, CA). Intracellular IDE was detected by immunofluorescence as described previously (Greenfield et al., 1999) with 9B12 and 28H1 monoclonal antibodies (Shii and Roth, 1986).

Immunoprecipitation-mass spectrometry analysis. Media or cell lysates were immunoprecipitated with 4G8 antibody and protein A/G-agarose beads. The molecular masses and concentrations of immunoprecipitated $\mathrm{A} \beta$ species were measured by matrix-assisted laser desorption/ionization time-of-flight mass spectrometry analysis, as described previously (Xu et al., 1998). For analysis, $\mathrm{A} \beta 12-28$ and insulin internal standards were added to the samples.

Sucrose gradient fractionation. Fractionation by sucrose gradient was performed as described previously (Greenfield et al., 1999). After $16 \mathrm{hr}$ of incubation in the absence or presence of $1 \mu \mathrm{M}$ insulin, N2a cells were homogenized by using a stainless steel ball bearing homogenizer in $5 \mathrm{vol}$ of $0.25 \mathrm{M}$ sucrose, $10 \mathrm{~mm}$ Tris- $\mathrm{HCl}, \mathrm{pH} \mathrm{7.4,1} \mathrm{mM} \mathrm{MgAc}$, and a protease inhibitor mixture. The homogenate was loaded on top of a step gradient comprised of $1.5 \mathrm{ml}$ of $2 \mathrm{M}$ sucrose, $4 \mathrm{ml}$ of $1.3 \mathrm{M}$ sucrose, $3.0 \mathrm{ml}$ of 1.16 $\mathrm{M}$ sucrose, and $2.0 \mathrm{ml}$ of $0.8 \mathrm{M}$ sucrose. All sucrose solutions contained 10 $\mathrm{mm}$ Tris- $\mathrm{HCl}, \mathrm{pH} 7.4$, and $1 \mathrm{~mm} \mathrm{MgAc}_{2}$. The gradients were centrif uged for $2.5 \mathrm{hr}$ at $100,000 \times g$ in a Beckman SW41Ti rotor. Fractions were collected and assayed for total protein with BCA assay. A $\beta$ and $\beta$ APP were assayed as described above. Proteins from each fraction were analyzed by Western blot with antibodies against calnexin, $\gamma$-adaptin (BD Transduction Laboratories), or ARF3 (Affinity BioReagents, Neshanic Station, NJ) to identify the fractions containing, respectively, endoplasmic reticulum (ER), TGN, and cytosol/post-TGN vesicles. To determine the fractions enriched in plasma membrane proteins, we fractionated N2a cells after biotinylation of surface proteins and detected biotinylated $\beta$ APP as described below.

Cell surface biotinylation. Biotinylation was performed on confluent monolayer N2a cells overexpressing $\beta$ APP695 by using sulfo-NHS-LCbiotin [sulfosuccinimidyl-6-(biotinamido)-hexanoate; Pierce, Rockford, IL]. The reagent was dissolved in PBS with calcium and magnesium, $\mathrm{pH}$ 7.2 , at $0.5 \mathrm{mg} / \mathrm{ml}$ and added twice to the cultures for $20 \mathrm{~min}$ at $4^{\circ} \mathrm{C}$. After thorough washing, the cells were lysed with $3 \%$ SDS as described above. $\beta$ APP was immunoprecipitated by using 369 antiserum and was analyzed by Western blot. Biotinylated $\beta$ APP was detected by using HRPconjugated streptavidin and reaction with a chemiluminescent substrate (NEN-DuPont).

Endoglycosidase-H Digestion. To evaluate the effect of insulin on ERto-Golgi trafficking of $\beta$ APP, we pulse-labeled N2a cells for 5 min with $750 \mu \mathrm{Ci} / \mathrm{ml}\left[{ }^{35} \mathrm{~S}\right]$ methionine (NEN-DuPont) in methionine-free DMEM and chased the cells for 5-45 $\mathrm{min}$ in the absence or presence of $1 \mu \mathrm{M}$ insulin as described above. $\left[{ }^{35} \mathrm{~S}\right]$-labeled $\beta$ APP was immunoprecipitated from the SDS-soluble lysates by 369 antiserum. The immune complexes were boiled for $5 \mathrm{~min}$ in a buffer containing $50 \mathrm{~mm}$ Tris- $\mathrm{HCl}, \mathrm{pH} 7.6$, $0.5 \%$ SDS, and $1 \% \beta$-mercaptoethanol to dissociate $\beta$ APP from the antibody; sodium citrate was added to a final concentration of $0.05 \mathrm{M}$. Then the samples were incubated in the presence or absence of $50 \mathrm{U}$ of endoglycosidase-H (New England Biolabs, Beverly, MA) at $37^{\circ} \mathrm{C}$ for 16 hr. $\beta$ APP isoforms were separated on a $6 \%$ Tris/glycine gel, transferred to PVDF membrane, and detected by autoradiography.

Quantification and densitometry. Gels were exposed to x-ray film, and the films were scanned with an Agfa Arcus II scanner. Band intensities were analyzed and quantified by using NIH Image Quant software, version 1.52. Statistical analysis was performed with ANOVA, followed by a post hoc test. 

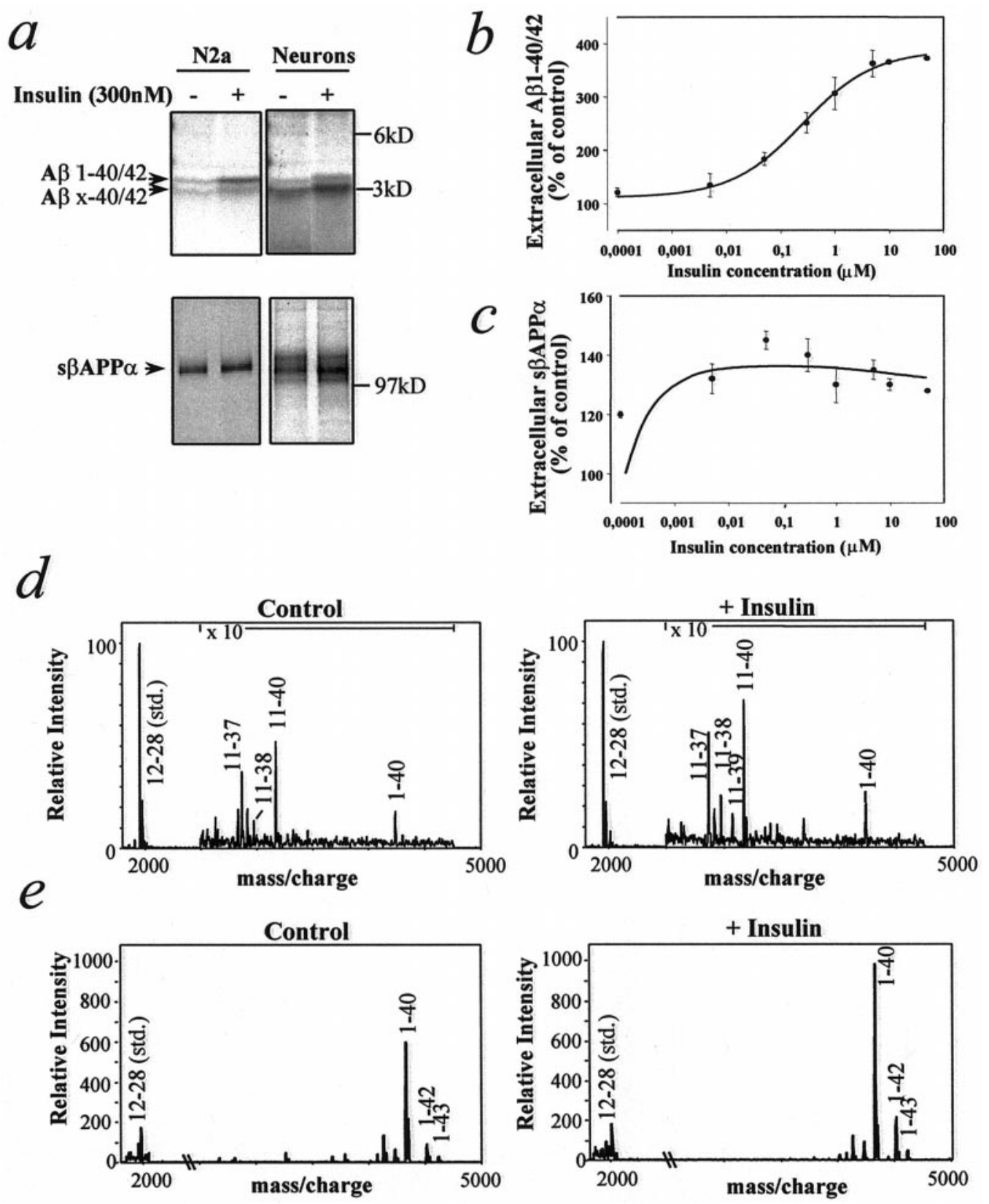

Figure 1. Effect of insulin on the extracellular levels of $\mathrm{A} \beta$ and s $\beta \mathrm{APP} \alpha$ in murine neuroblastoma cells $(N 2 a)$ and primary rat cortical neuronal cultures. Cells were pulse-labeled for 20 min with $\left[{ }^{35}\right.$ S]methionine and incubated in serum-free medium in the absence or presence of various concentrations of insulin for $4 \mathrm{hr} . a$, Representative autoradiographic analysis of extracellular A $\beta$ (top) and s $\beta \mathrm{APP} \alpha$ (bottom) after incubation with or without 300 nM insulin. $b$, Extracellular levels of $\mathrm{A} \beta$ from N2a cells as a function of insulin concentration. $c$, Extracellular levels of s $\beta \mathrm{APP} \alpha$ from N2a cells as a function of insulin concentration. For $b$ and $c$ the data represent means $\pm \mathrm{SD} ; n=3$. $d, e, \mathrm{IP}-\mathrm{MS}$ analysis of extracellular $\mathrm{A} \beta$ from primary neurons $(d)$ and $\mathrm{N} 2 \mathrm{a}$ cells $(e)$ after incubation in the absence or presence of $1 \mu \mathrm{M}$ insulin for $4 \mathrm{hr}$.

\section{RESULTS}

\section{Insulin increases extracellular levels of $\mathbf{A} \beta 40$ and $\mathbf{A} \boldsymbol{\beta} 42$}

To examine the effect of insulin on $\beta$ APP metabolism, we pulselabeled neuroblastoma (N2a) cells overexpressing human BAPP695 or primary cultures of rat cortical neurons with $\left[{ }^{35} \mathrm{~S}\right]$ methionine for $20 \mathrm{~min}$ and chased the cells in the absence or presence of insulin for $4 \mathrm{hr}$. Cells that were treated with insulin showed a three- to fourfold increase in extracellular levels of both $4 \mathrm{kDa} A \beta 1-40 / 42$ and $3 \mathrm{kDa} N$-terminally truncated $\mathrm{A} \beta \mathrm{x}-40 / 42$ peptides, mainly composed of A $\beta 11-40 / 42$ (Gouras et al., 1998)
(Fig. 1a, top). The effect of insulin on extracellular levels of A $\beta 1-40 / 42$ was concentration-dependent, with a minimal effective concentration of $\sim 50 \mathrm{~nm}$ and a half-maximal effect at $\sim 300$ nM (Fig. 1b). Insulin caused a $\sim 1$.4-fold increase in $\operatorname{s} \beta A P P \alpha$ extracellular levels (Fig. 1a, bottom, $c$ ), with a small increase occurring at the lowest concentration $(0.2 \mathrm{nM})$ that was tested. Secretion of $\mathrm{s} \beta \mathrm{APP} \beta$ was not altered by insulin treatment (data not shown). Immunoprecipitation-mass spectrometry (IP-MS) analysis revealed increases in extracellular $\mathrm{A} \beta 1-40$ in both primary neurons and N2a cells (Fig. 1d,e) and increases of A $\beta 1-42$ 


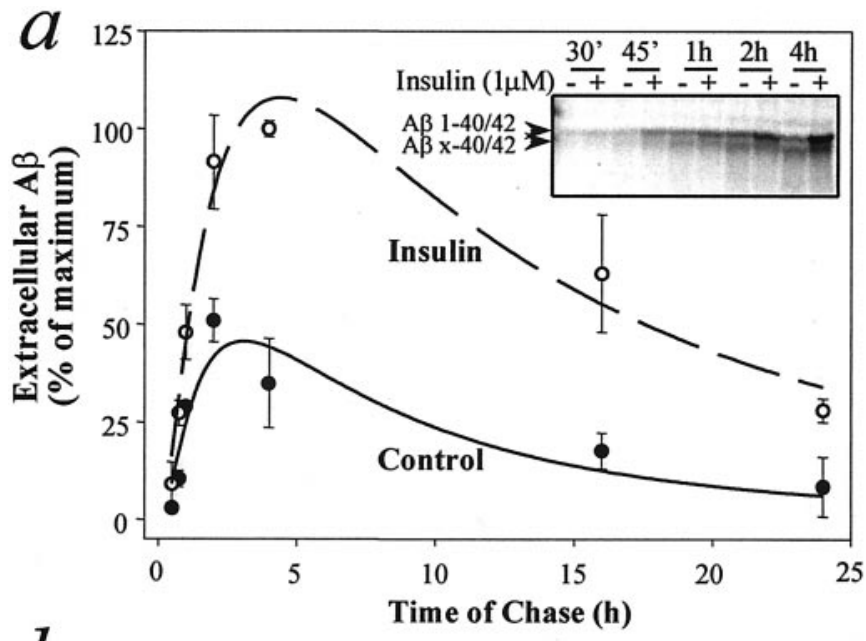

$b$

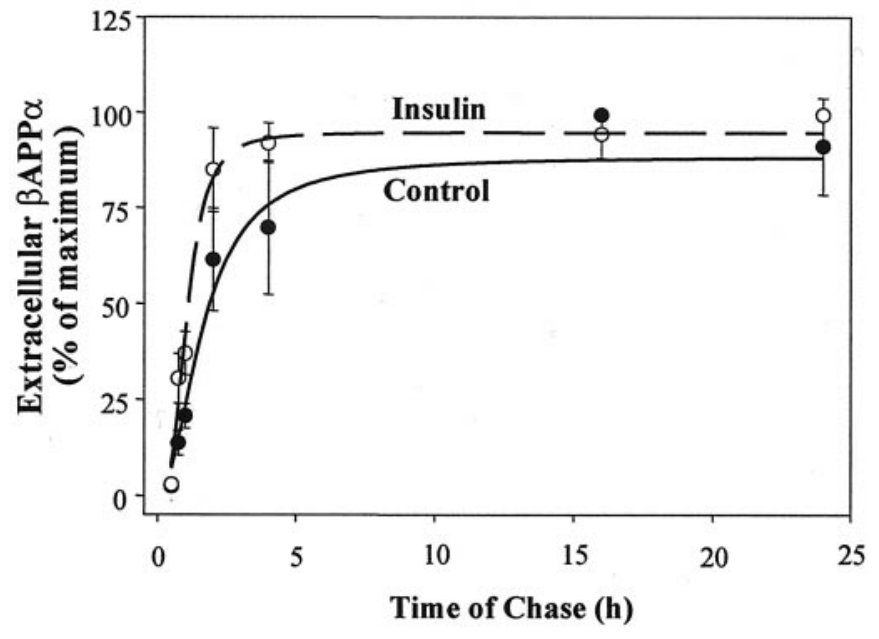

Figure 2. Time course of $\mathrm{A} \beta(a)$ and $\mathrm{s} \beta \mathrm{APP} \alpha(b)$ extracellular levels from N2a cells in the absence or presence of insulin. Cells were pulselabeled with $\left[{ }^{35} \mathrm{~S}\right] \mathrm{methionine}$ for $20 \mathrm{~min}$ and incubated in serum-free medium in the absence or presence of $1 \mu \mathrm{M}$ insulin for different intervals. Data represent means $\pm \mathrm{SD} ; n=3$. Inset in $a$ shows a representative autoradiographic analysis of extracellular $\mathrm{A} \beta$ after periods of chase from $30 \mathrm{~min}$ to $4 \mathrm{hr}$.

in N2a cells (Fig. 1e). The effect of insulin on the extracellular levels of $\mathrm{A} \beta 1-40 / 42$ and $\mathrm{A} \beta \mathrm{x}-40 / 42$ in cultures of $\mathrm{N} 2 \mathrm{a}$ cells was evident at all incubation times from $30 \mathrm{~min}$ to $24 \mathrm{hr}$ (Fig. $2 a$ ). A $\beta$ secretion in the absence or presence of insulin peaked at $4 \mathrm{hr}$ and decreased thereafter, indicating that $\mathrm{A} \beta$ is susceptible to degradation by proteases released from the cells. Extracellular s $\beta \mathrm{APP} \alpha$ was increased slightly by insulin at early, but not at late, incubation times (Fig. 2b) and reached a plateau level because of its resistance to the degrading activity of proteases. $\beta$ APP levels were not altered by insulin during pulse-chase experiments. Glucose-containing medium was required for the action of insulin on $\mathrm{A} \beta$. Glucose concentrations higher than the standard growing concentration did not alter basal or insulin-stimulated $\mathrm{A} \beta$ levels (data not shown).

\section{Insulin increases extracellular $\mathrm{A} \beta$ both by reducing IDE-mediated $\mathbf{A} \beta$ degradation and by stimulating $\mathbf{A} \beta$ secretion}

To investigate whether the increased level of extracellular $A \beta$ was attributable at least in part to the inhibition of extracellular degradation, we examined the effect of IDE on the levels of extracellular A $\beta$. IDE was found intracellularly by immunocytochemistry (data not shown), and pulse-chase experiments demonstrated a substantial amount of IDE in the medium of primary neuronal cultures after a $16 \mathrm{hr}$ chase (Fig. $3 a$ ). It was reported previously that IDE can cause the rapid degradation of A $\beta 1-40$ / 42 , but not $\mathrm{A} \beta \mathrm{x}-40 / 42$, and that the enzymatic activity of IDE against $A \beta 1-40 / 42$ could be prevented by insulin, phenantroline, or immunodepletion with an IDE-specific antibody (Qiu et al., 1998; Vekrellis et al., 2000). We have confirmed those earlier studies in the present investigation (Fig. 3b,c). Insulin and phenantroline each acted as a potent inhibitor of the degradation of $\mathrm{A} \beta$ by IDE in our in vitro setting (Fig. $3 c$ ). However, insulin, phenantroline, or immunodepletion of IDE from our system did not rescue $\mathrm{A} \beta$ completely from degradation, suggesting that other proteases may be involved in $\mathrm{A} \beta$ breakdown. To investigate whether insulin can stimulate the secretion of $\mathrm{A} \beta$ in addition to preventing its degradation, we treated N2a cells with or without insulin in the absence or presence of the IDE inhibitor 1,10phenantroline for various time intervals (Fig. $3 d$ ). Phenantroline alone increased the extracellular levels of $\mathrm{A} \beta$. However, the effect of phenantroline was less than that of insulin alone and was significant only at later intervals $(4-16 \mathrm{hr})$. When phenantroline was present during the incubation period to inactivate IDE, insulin further enhanced the extracellular levels of $\mathrm{A} \beta$. These results indicate that insulin can stimulate $\mathrm{A} \beta$ secretion in addition to inhibiting IDE-mediated $\mathrm{A} \beta$ degradation. In addition, the secretion of the $3 \mathrm{kDa} N$-terminally truncated $\mathrm{A} \beta \mathrm{x}-40 / 42$ peptides, which are resistant to degradation by IDE (Qiu et al., 1998; Vekrellis et al., 2000) (Fig. 3b), was stimulated by insulin (see Figs. 1a, 2a).

\section{Insulin reduces intracellular $\mathrm{A} \beta 40$ and $\mathrm{A} \beta 42$}

To examine further the role of insulin in $\beta$ APP metabolism, we examined the effect of insulin on intracellular $A \beta$, which recently has been hypothesized to be important in AD (Wild-Bode et al., 1997; Skovronsky et al., 1998; Chui et al., 1999; Wilson et al., 1999; Gouras et al., 2000; Mochizuki et al., 2000). N2a cells were treated with $1 \mu \mathrm{M}$ insulin for 4 or $16 \mathrm{hr} ; \mathrm{A} \beta$ was extracted with SDS and analyzed by immunoprecipitation and SDS-PAGE. Intracellular $\mathrm{A} \beta$ was reduced by $20 \%$ after $4 \mathrm{hr}$ and by $45 \%$ after 16 hr of insulin treatment (Fig. 4a,b). Immunoprecipitation-mass spectrometry analysis revealed that intracellular $\mathrm{A} \beta 40$ and $\mathrm{A} \beta 42$ both were reduced after insulin treatment (Fig. $4 c$ ). No change was detected in the levels of full-length $\beta$ APP or PS- 1 N-terminal fragment after insulin treatment for $4 \mathrm{hr}$ (data not shown) or 16 hr (Fig. 4d,e).

\section{Insulin reduces $A \beta$ in the Golgi/TGN by accelerating $\boldsymbol{\beta A P P} / \mathrm{A} \boldsymbol{\beta}$ transport to the plasma membrane}

$\beta$ APP resides predominantly in the Golgi/TGN, which is also the main site of A $\beta$ generation (Cook et al., 1997; Hartmann et al., 1997; Xu et al., 1997; Lee et al., 1998; Skovronsky et al., 1998; Greenfield et al., 1999). Insulin is known to stimulate protein transport from TGN or post-TGN vesicles to the plasma membrane (Pessin et al., 1999). To define the subcellular compartments in which insulin exerts its action on $\beta \mathrm{APP}$ and $\mathrm{A} \beta$ trafficking, we performed subcellular fractionation by using a well characterized sucrose gradient procedure (Greenfield et al., 1999) after $16 \mathrm{hr}$ of incubation in the absence or presence of insulin. Insulin reduced $\mathrm{A} \beta$ in membrane fractions collected from 


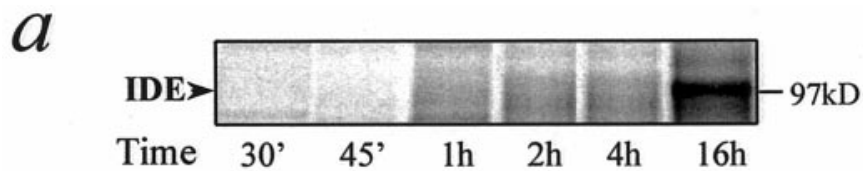

$b$
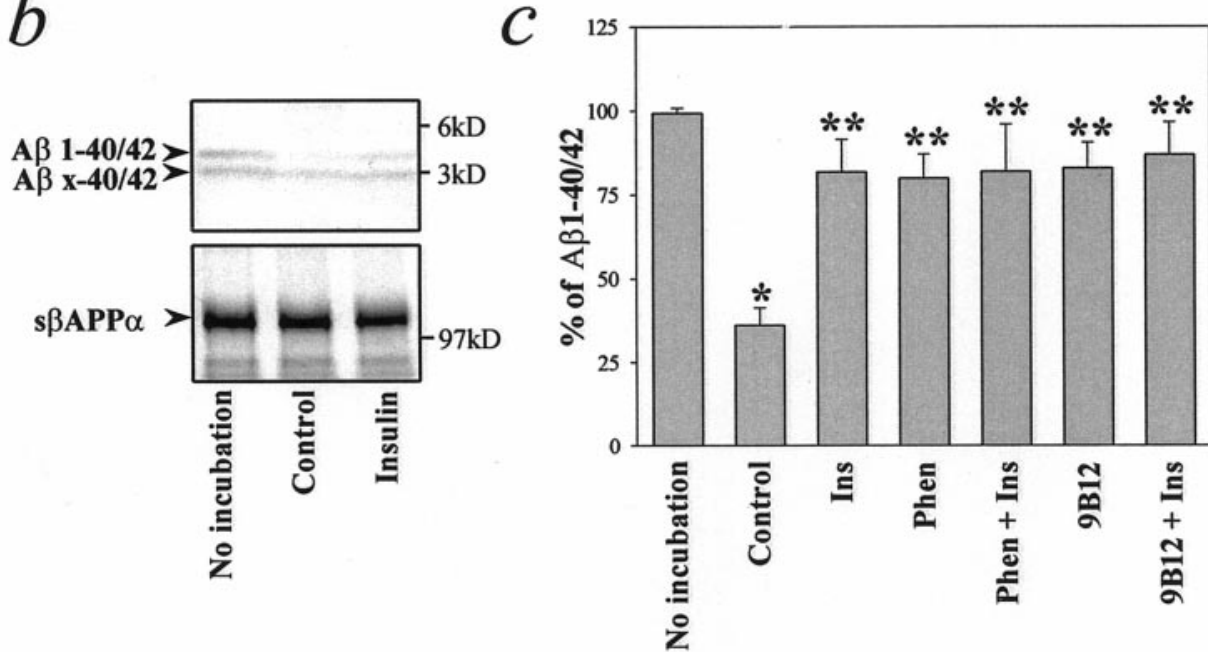

$d$

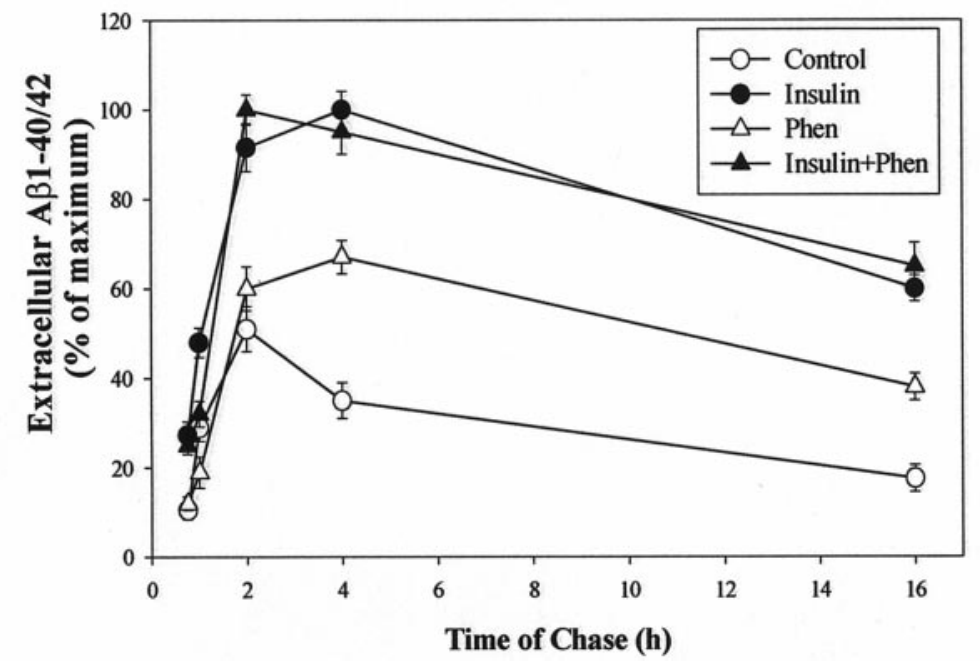

Figure 3. Insulin inhibits $\mathrm{A} \beta$ degradation via IDE and stimulates the secretion of A $\beta . a$, IDE released in the medium from cultured neurons as a function of time. Primary cortical neurons were pulse-labeled for $20 \mathrm{~min}$ and chased for different intervals up to $16 \mathrm{hr}$. IDE was immunoprecipitated with $28 \mathrm{H} 1$ monoclonal antiIDE antibody and analyzed on SDS-PAGE. $b$, $c$, N2a cells were incubated for $4 \mathrm{hr}$ with $\left[{ }^{35} \mathrm{~S}\right]$ methionine to produce labeled $\mathrm{A} \beta$ and $\operatorname{s} \beta$ APP $\alpha$. Serum-free conditioned medium was collected from cultured primary neurons, which had been incubated for $16 \mathrm{hr}$ at $37^{\circ} \mathrm{C}$. Then this medium was mixed with the medium containing labeled $\mathrm{A} \beta$ or $\mathrm{s} \beta \mathrm{APP} \alpha$ and incubated for a further $16 \mathrm{hr}$ in the absence or presence of the indicated substances (see Materials and Methods). $b$, Insulin inhibits $\mathrm{A} \beta$ degradation. Shown is an autoradiographic analysis of labeled $\mathrm{A} \beta$ (top) and $\mathrm{s} \beta \mathrm{APP} \alpha$ (bottom). Media were collected before or after in vitro incubation in the absence or presence of $1 \mu \mathrm{M}$ insulin, immunoprecipitated with anti-A $\beta$ (4G8) or anti-s $\beta$ APP (22C11) antibodies, and analyzed on SDSPAGE. Insulin caused a marked inhibition of A $\beta 1-40 / 42$ degradation. $c$, IDE-mediated A $\beta$ degradation was inhibited by $1 \mu \mathrm{M}$ insulin (Ins), $1 \mathrm{~mm}$ 1,10-phenantroline (Phen), or immunodepletion of IDE with a monoclonal antiIDE antibody (9B12; see Materials and Methods). Data represent means $\pm \mathrm{SD} ; n=3 .{ }^{*} p<$ 0.01 with respect to the sample with no incubation; ${ }^{* *} p<0.01$ with respect to control sample. $d$, Insulin stimulates $\mathrm{A} \beta$ secretion. $\mathrm{N} 2 \mathrm{a}$ cells were pulse-labeled for $20 \mathrm{~min}$ and chased for various times in the absence or presence of 1 $\mu \mathrm{M}$ insulin, $1 \mathrm{~mm}$ 1,10-phenantroline (Phen), or a combination of the two compounds. Data represent means $\pm \mathrm{SD} ; n=3$. the interfaces corresponding to secretory vesicles and Golgi/ TGN, but not from those corresponding to heavy membranes such as the ER, plasma membranes, and lysosomes (Fig. 5a,b). Moreover, after a $2 \mathrm{hr}$ preincubation of cells at $20^{\circ} \mathrm{C}$ to accumulate newly synthesized $\left[{ }^{35} \mathrm{~S}\right]$-labeled $\beta A P P$ in the TGN, insulindependent secretion of $\mathrm{A} \beta$ and $\operatorname{s} \beta \mathrm{APP} \alpha$ was observed within 7.5-15 min of the addition of the hormone (data not shown), supporting the idea that insulin stimulates $\mathrm{A} \beta$ and $\mathrm{s} \beta \mathrm{APP} \alpha$ trafficking from the TGN. After insulin treatment, full-length $\beta$ APP also is reduced in vesicle and Golgi-enriched fractions, whereas it is increased in the heavy membrane fractions (Fig. $5 c, d$ ). The total amount of $\beta$ APP was not changed overall by insulin treatment (see Fig. 4d). Calnexin (ER), $\gamma$-adaptin (TGN), ARF3 (post-TGN vesicles, cytosol), and surface biotinylated $\beta$ APP (plasma membranes) were assayed to identify fractions that are enriched in these organelles (Fig. 5e). Our data indicate that insulin reduces intracellular $\mathrm{A} \beta$ and stimulates its secretion by increasing the $\beta \mathrm{APP} / \mathrm{A} \beta$ egress from the Golgi/TGN and from
post-TGN vesicles. To determine whether the effect of insulin on trafficking was reflected in the number of $\beta$ APP molecules on the plasma membrane, we treated N2a cells for $4 \mathrm{hr}$ with insulin and then labeled them with biotin. Insulin treatment resulted in an almost twofold increase in $\beta$ APP molecules at the cell surface (Fig. 5f).

\section{Insulin does not affect ER-to-Golgi transport}

It has been shown that insulin stimulates the export of leptin from the ER in rat adipocytes (Barr et al., 1997). However, an effect of insulin on ER-to-Golgi transport has not been reported for any other protein. To investigate whether insulin could affect $\beta$ APP trafficking between ER and Golgi, we pulse-labeled N2a cells for $5 \mathrm{~min}$ and chased them for up to $45 \mathrm{~min}$ in the absence or presence of insulin. Immunoprecipitated $\beta$ APP molecules were subjected to endoglycosidase-H (Endo- $\mathrm{H})$ digestion, and the rate of appearance of Endo-H-resistant, N-linked oligosaccharidemodified isoforms of $\beta$ APP was evaluated. Newly synthesized 
Figure 4. Insulin reduces intracellular levels of $\mathrm{A} \beta$ in N2a cells. Cells were treated for 4 or $16 \mathrm{hr}$ with or without $1 \mu \mathrm{M}$ insulin and lysed in SDS. $a, b$, Intracellular $\mathrm{A} \beta$ was detected by immunoprecipitation with 4G8, followed by SDS-PAGE and Western blotting, using 6E10 monoclonal antibody, which recognizes only A $\beta 1-40 / 42$. $a$, Representative autoradiographic analysis of intracellular $\mathrm{A} \beta$ after $16 \mathrm{hr}$ of treatment in the absence or presence of $1 \mu \mathrm{M}$ insulin. $b$, Quantitative analysis of intracellular $\mathrm{A} \beta$ after treatment with insulin for 4 or $16 \mathrm{hr}$. Data represent means $\pm \mathrm{SD} ; n=$ 5. ${ }^{*} p<0.05$ versus control. $c$, IP-MS analysis of intracellular A $\beta 40 / 42$ levels after $4 \mathrm{hr}$ of treatment with $1 \mu \mathrm{M}$ insulin. $d, e$, Western blot analysis for full-length $\beta$ APP $(d)$ and the PS- $1 \mathrm{~N}$-terminal fragment $(e)$ after $16 \mathrm{hr}$ of treatment with $1 \mu \mathrm{M}$ insulin.
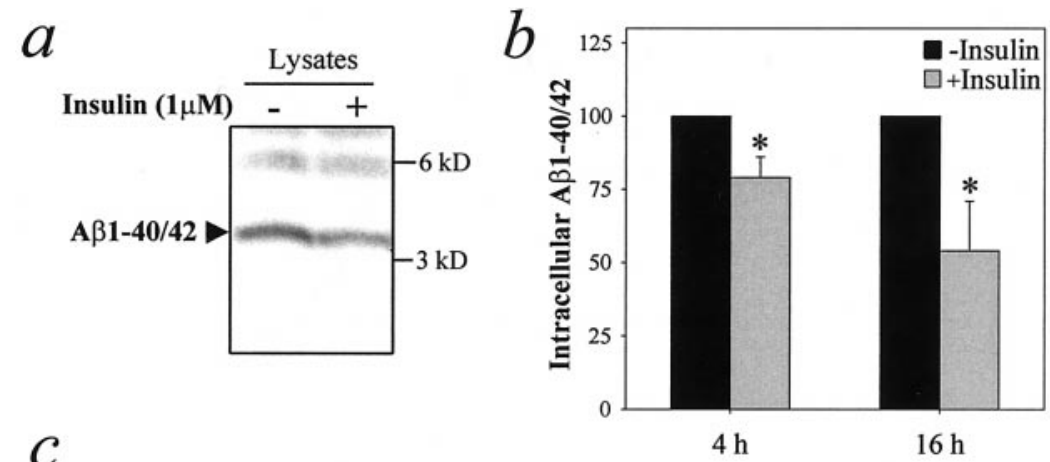

C
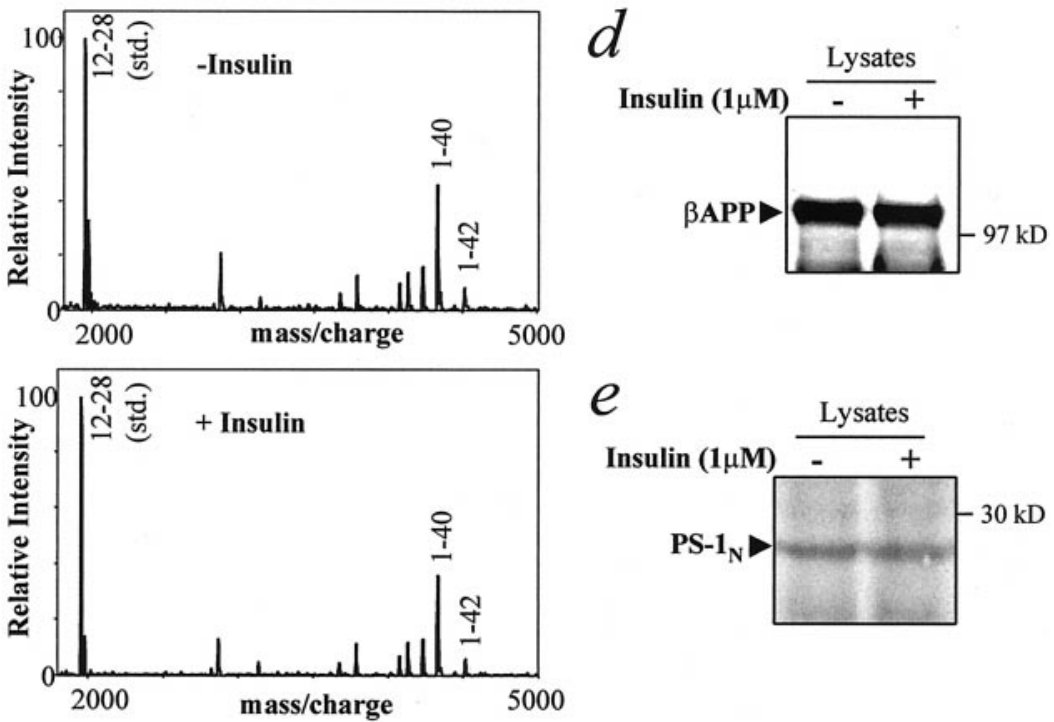

$\beta$ APP $(\sim 105 \mathrm{kDa})$ is sensitive to digestion by Endo-H (Fig. $6 ; t=$ $0 \mathrm{~min})$. After $5-10 \mathrm{~min}$ of chase, a $\sim 115 \mathrm{kDa} \beta A P P$ form appeared that was resistant to Endo-H digestion. Clearly, insulin treatment did not alter $\beta$ APP maturation significantly or the pattern of Endo-H resistance, an indicator of ER-to-Golgi trafficking, at any time of chase up to $45 \mathrm{~min}$.

\section{Insulin regulates $\beta$ APP processing via a receptor tyrosine kinase}

Insulin receptors are present in both $\mathrm{N} 2 \mathrm{a}$ and primary neuronal cultures (Fig. 7a). To determine whether the action of insulin involves a tyrosine kinase, we inhibited intrinsic tyrosine kinase activity with tyrphostin-25, a nonselective inhibitor of receptor and nonreceptor tyrosine kinases, and measured its effect on insulin-stimulated $\mathrm{A} \beta$ secretion in $\mathrm{N} 2 \mathrm{a}$ cells. Tyrphostin-25 (25 $\mu \mathrm{M})$ abolished the effect of insulin on $\mathrm{A} \beta$ secretion, which was accompanied by a small reduction in basal secretion (Fig. $7 b$ ). At a concentration of $10 \mu \mathrm{M}$, tyrphostin-25 partially inhibited the effect of insulin on $A \beta$ levels without any effect on basal secretion (data not shown). These results indicate that tyrosine kinase activity is essential for the effect of insulin on $\mathrm{A} \beta$ trafficking. In addition, the effect of insulin on $\mathrm{A} \beta$ was mimicked by IGF-1, but not by glucagon, EGF, NGF, PDGF, aFGF, or bFGF (data not shown), indicating the specificity of the insulin effect. These various results indicate that the effect of insulin is mediated via interaction with the insulin/IGF-1 receptor.

\section{Insulin regulates $\beta$ APP processing via MEK/MAP kinase cascade}

To investigate the insulin pathway downstream of the insulin receptor, we studied the effect of selective inhibitors of three known insulin-activated signal transduction cascades. PD98059, a highly selective inhibitor of MAP kinase kinase activation (Alessi et al., 1995; Dudley et al., 1995), abolished the effect of insulin on $\mathrm{A} \beta$ secretion (Fig. $7 c$ ) and intracellular $\mathrm{A} \beta$ (data not shown) without altering basal levels of these parameters. In contrast, wortmannin, an inhibitor of PI-3 kinase, and U73122, an inhibitor of phospholipase $\mathrm{C}$, caused a nonselective inhibition of both basal- and insulin-stimulated secretion of $\mathrm{A} \beta$ after incubation for 4 hr (Fig. 7c).

\section{DISCUSSION}

The present observations, that intracellular $\mathrm{A} \beta$ decreases whereas extracellular $A \beta$ increases in response to insulin, could be explained by a mechanism involving insulinstimulated intracellular trafficking of $\beta$ APP and $\mathrm{A} \beta$. This proposal is supported by substantial evidence showing that insulin selectively stimulates protein transport through the secretory pathway (Bogan and Lodish, 1999). In fact, we report here that insulin (1) accelerates $\beta \mathrm{APP} / \mathrm{A} \beta$ trafficking from the TGN, the main site of $\mathrm{A} \beta$ generation, to the plasma membrane; (2) increases the number of $\beta$ APP molecules on the plasma membrane; (3) increases the extracellular levels of $\mathrm{A} \beta$ even when IDE is inhibited by phenantroline; and (4) increases the 


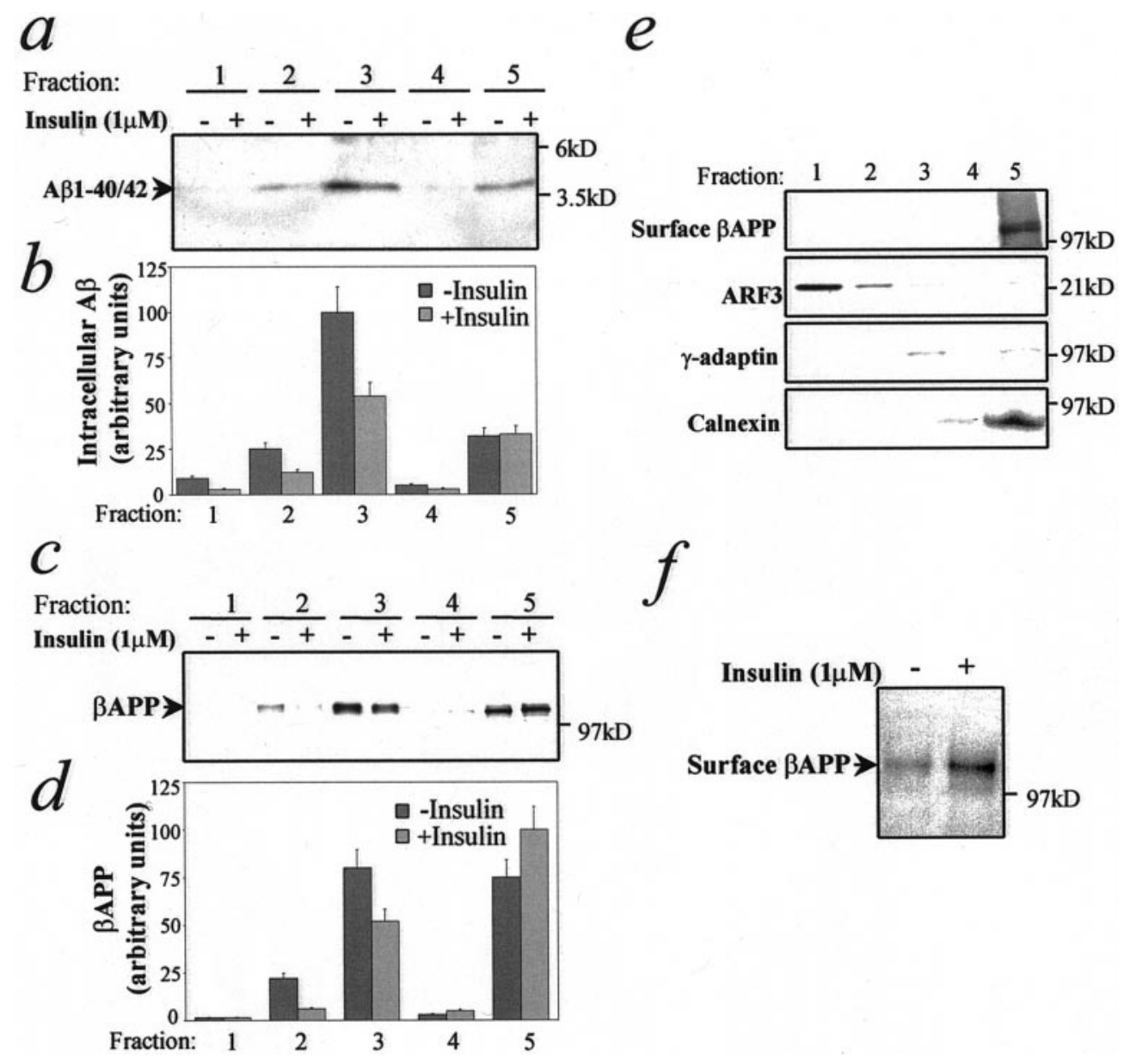

Figure 5. Insulin influences $\mathrm{A} \beta$ and $\beta$ APP trafficking in N2a cells. Cells were treated for $16 \mathrm{hr}$ in the absence or presence of $1 \mu \mathrm{M}$ insulin, homogenized, and fractionated on an equilibrium flotation sucrose gradient (see Materials and Methods). $a$, Representative autoradiographic analysis and quantitative analysis $(b)$ of $\mathrm{A} \beta$ subcellular distribution after insulin treatment. $c$, Representative autoradiographic analysis and quantitative analysis (d) of intracellular $\beta$ APP subcellular distribution after insulin treatment. $e$, Markers for subcellular compartments. Proteins from each fraction were precipitated by trichloroacetic acid and analyzed by Western blot, using the antibodies anticalnexin (ER), anti- $\gamma$-adaptin (TGN), or anti-ARF3 (post-TGN vesicles, cytosol). Surface $\beta$ APP (plasma membrane) was determined as described (see Materials and Methods). Fraction $1=0.25 \mathrm{M}$ sucrose solution (loading, cytosol). Fractions 2-5 correspond, respectively, to interfaces between $0.25 / 0.8 \mathrm{M}$ (post-TGN vesicles), $0.8 / 1.16 \mathrm{~m}$ (Golgi/TGN), 1.16/1.3 $\mathrm{M}$, and $1.3 \mathrm{M} / 2 \mathrm{M}$ (heavy membranes such as ER, plasma membranes) sucrose solutions. $f$, N2a cells were treated for $4 \mathrm{hr}$ in the absence or presence of $1 \mu \mathrm{M}$ insulin. Surface proteins were labeled with biotin. Biotinylated $\beta$ APP was analyzed by immunoprecipitation with 369 antibody and Western blot with HRP-conjugated streptavidin.
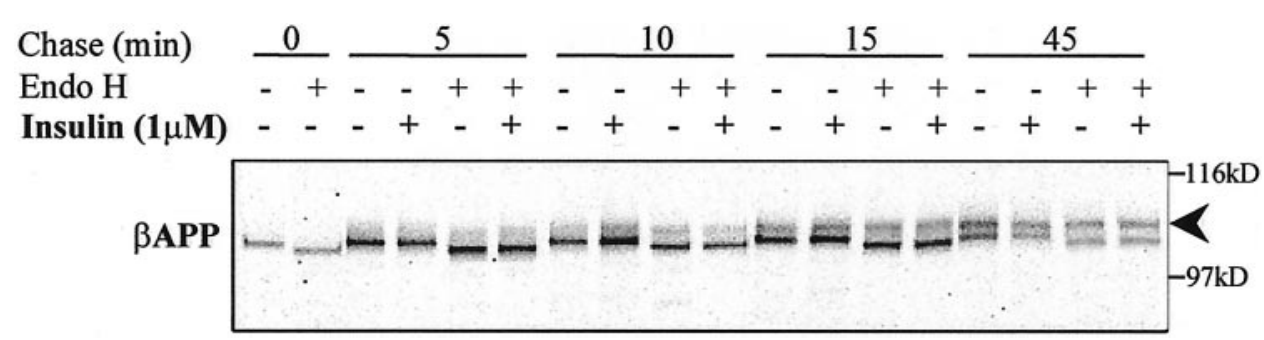

Figure 6. Lack of effect of insulin on $\beta A P P$ trafficking from ER to Golgi. N2a cells were pulse-labeled for $5 \mathrm{~min}$ with $\left[{ }^{35} \mathrm{~S}\right] \mathrm{methionine}$ and chased in serum-free medium in the absence or presence of 1 $\mu \mathrm{M}$ insulin for 5-45 min. $\beta$ APP was immunoprecipitated by using 369 antibody; one-half of the sample was digested by endoglycosidase-H (Endo $H$ ). The arrowhead indicates the endoglycosidase- $\mathrm{H}$ resistant $\beta$ APP species.

secretion of $3 \mathrm{kDa} A \beta \mathrm{x}-40 / 42$ peptides, mainly composed of A $\beta 11-40 / 42$ (Gouras et al., 1998), which are resistant to IDE degradation (Qiu et al., 1998; Vekrellis et al., 2000). $\beta A P P$ levels and $\mathrm{s} \beta \mathrm{APP} \beta$ secretion were not affected by insulin, suggesting that insulin may not regulate the $\beta$-cleavage of $\beta$ APP but only $\beta \mathrm{APP} / \mathrm{A} \beta$ trafficking. Elucidation of the potential contribution of the endosomal compartments to the effect of insulin on $\mathrm{A} \beta$ secretion awaits further investigation.

In agreement with previous studies (Qiu et al., 1998; Vekrellis et al., 2000), we have found in using both neuronal cell lines and primary neuronal cultures that IDE is a protease involved in $\mathrm{A} \beta$ degradation and that insulin inhibits $\mathrm{A} \beta$ degradation by competing for IDE. It was reported previously that IDE can be secreted by microglial cell cultures (Qiu et al., 1998), whereas it is cell-associated in primary neurons (Vekrellis et al., 2000). Although a significant amount of IDE is detectable in the medium of primary neurons after $16 \mathrm{hr}$, this is likely an experimental artifact of the cell culture setting, because IDE does not have the signal peptide required for targeting into the secretory pathway and therefore should not be secreted. The slow kinetics of IDE release further support this view. Evidence was presented recently that a neutral endopeptidase, but not IDE, was involved in $\mathrm{A} \beta$ degradation when radiolabeled $\mathrm{A} \beta$ was injected into rat brain (Iwata et al., 2000). Thus, IDE-mediated $\mathrm{A} \beta$ degradation may be of less physiological relevance in vivo. In addition, proteases other than IDE also may take part in $\mathrm{A} \beta$ degradation in neuronal cultures, as suggested by the incomplete inhibition of $\mathrm{A} \beta$ degradation by insulin, phenantroline, or immunodepletion of IDE in our in vitro system (see Fig. $3 c$ ). This possibility is supported further by the observation that $\mathrm{A} \beta$ was still degraded when neuronal cultures were treated with phenantroline to inactivate IDE (see Fig. 3d).

We have performed a number of experiments on the signal transduction pathway by which insulin might stimulate the intracellular trafficking of $\beta$ APP and $\mathrm{A} \beta$. The effect of insulin was 
Figure 7. The effect of insulin requires tyrosine kinase activity and is mediated via the MEK/MAP kinase cascade. $a$, Western blot analysis for insulin receptor $(I R)$ in N2a cells and primary neurons. $b$, $\mathrm{N} 2 \mathrm{a}$ cells were incubated for $16 \mathrm{hr}$ in serum-free medium in the absence or presence of $1 \mu \mathrm{M}$ insulin and/or $25 \mu \mathrm{M}$ tyrphostin-25. Data represent means $\pm \mathrm{SD} ; n=3$. ${ }^{*} p<0.05$ with respect to no addition; $* * p<0.05$ with respect to treatment with insulin alone; ${ }^{\dagger}$ Not significant with respect to tyrphostin-25 alone. $c$, N2a cells were incubated for $4 \mathrm{hr}$ in serum-free medium in the absence or presence of $1 \mu \mathrm{M}$ insulin, $25 \mu \mathrm{M}$ U73122, $500 \mathrm{nM}$ wortmannin, and/or $10 \mu \mathrm{M}$ PD98059. Data represent means $\pm \mathrm{SD} ; n=3 .{ }^{*} p<0.05$ with respect to no addition; ${ }^{* *} p<0.05$ with respect to treatment with insulin alone.

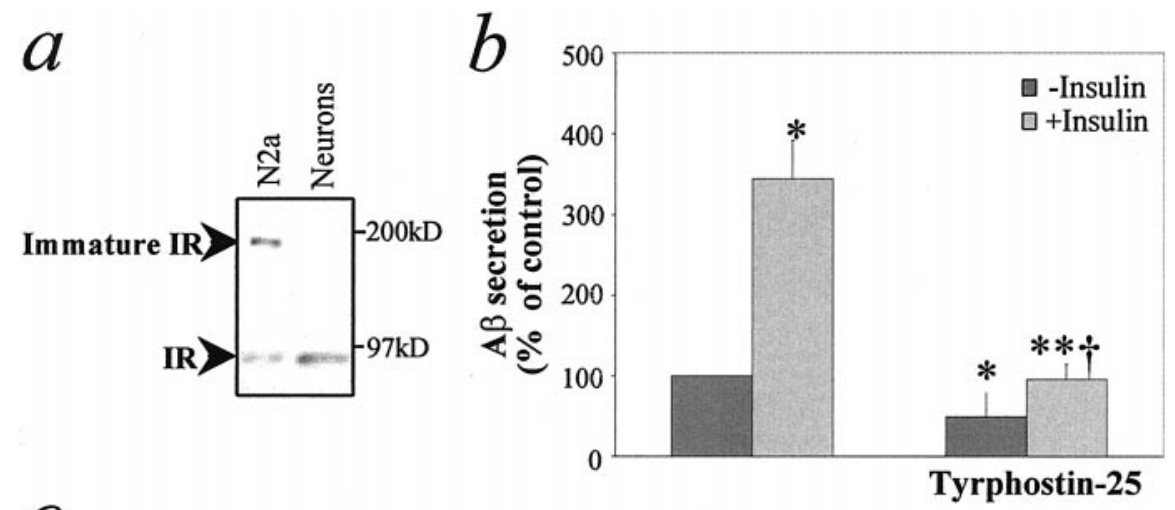

c

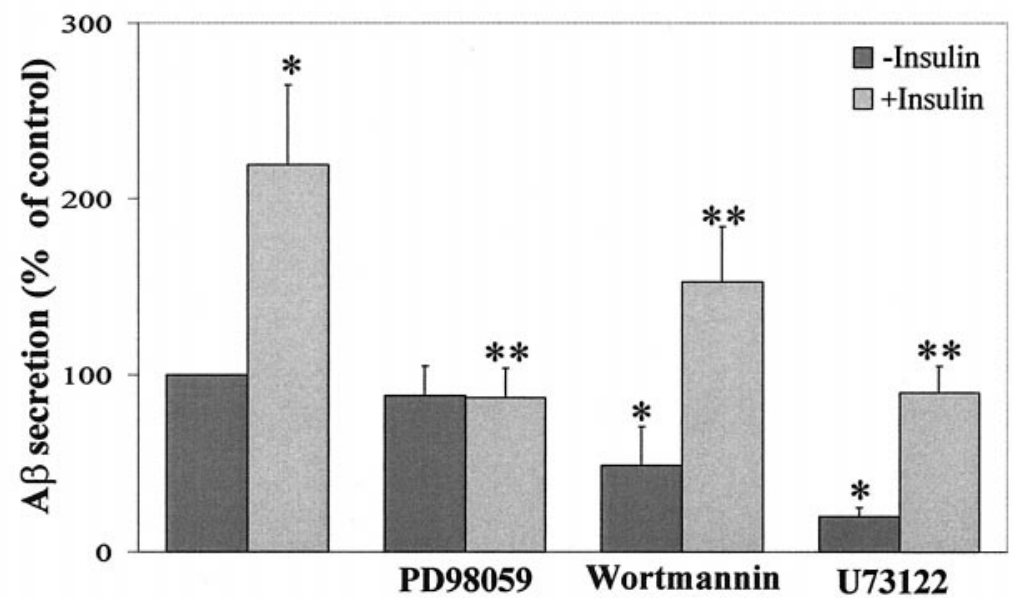

abolished by tyrphostin- 25 and was not mimicked by several other growth factors, indicating that the activation of the insulin/IGF-1 receptor tyrosine kinase is required for insulin-dependent $\mathrm{A} \beta$ secretion. Many of the present studies were performed by using a concentration of insulin of $1 \mu \mathrm{M}$. Although at this concentration a contribution of IGF-1 receptor could not be excluded, the fact that insulin is effective at a concentration of $50 \mathrm{~nm}$ indicates the specificity of its effect. A similar effect of IGF-1 on $\beta$ APP metabolism is to be expected because activation of IGF-1 receptors triggers the same downstream signaling molecules as those of insulin receptors (Lopaczynski, 1999). In an effort to elucidate the signaling pathway downstream of the insulin receptor, we studied the effect of selective inhibitors of the three known insulin-activated signal transduction cascades. The effect of insulin on $\mathrm{A} \beta$ secretion was abolished by PD98059, a highly selective inhibitor of the activation of the MAP kinase kinase (Alessi et al., 1995; Dudley et al., 1995), indicating that the effect of insulin is mediated by activation of the MAP kinase cascade. In contrast, wortmannin, an inhibitor of PI3-kinase, and U73122, a potent inhibitor of phospholipase $\mathrm{C}$, nonselectively reduced basal- and insulin-stimulated secretion of $\mathrm{A} \beta$.

Accumulation of $\mathrm{A} \beta$ plaques within the brain is widely believed to initiate the pathological cascade culminating in clinical AD. Generally, it is assumed that secreted $\mathrm{A} \beta$, and particularly $\mathrm{A} \beta 42$, plays a crucial role in amyloid neuropathology. Recent evidence suggests the hypothesis that intracellular A $\beta 42$ may play an important role in amyloid deposition and neuronal degeneration (for review, see Wilson et al., 1999; Gouras et al., 2000): high intracellular levels of $\mathrm{A} \beta 42$ are observed in cell lines expressing FAD mutant PS-1 (Wild-Bode et al., 1997); an insoluble pool of $\mathrm{A} \beta 42$ increases in a neuronal cell line during aging in culture (Skovronsky et al., 1998); intraneuronal accumulation of $\mathrm{A} \beta 42$ and extensive neuronal degeneration occur in the absence of $\mathrm{A} \beta$ plaques in transgenic mice expressing an FAD mutant form of PS-1 (Chui et al., 1999). Recent immunohistochemical studies have reported intraneuronal $\mathrm{A} \beta 42$ accumulation in early (Gouras et al., 2000) and late (Mochizuki et al., 2000) AD. Although direct neurotoxicity of intracellular $\mathrm{A} \beta$ has not been demonstrated, we cannot exclude that intracellular $\mathrm{A} \beta 42$ may play a direct role in initiating AD neuropathology.

Although basal insulin levels do not appear to be reduced in aging, insulin resistance and impaired insulin release in response to a glucose challenge are age-related phenomena (for review, see Lamberts et al., 1997; Perry, 1999). Several clinical studies suggest that insulin plays an important role in cognitive function and memory (for review, see Wickelgren, 1998; Lovestone, 1999). Recent findings demonstrated insulin receptor upregulation and reduced insulin receptor-mediated tyrosine kinase activity in AD brains (Frolich et al., 1998, 1999). Higher-fasting plasma insulin levels and reduced cerebrospinal fluid-to-plasma ratios of insulin, indicative of insulin resistance, have been described in patients with AD (Craft et al., 1998, 1999). Although recent crosssectional and prospective population-based studies have indicated that diabetes mellitus is a risk factor for dementia and AD (Yoshitake et al., 1995; Ott et al., 1996; Leibson et al., 1997), the issue is still controversial (Landin et al., 1993; Mortel et al., 1993; Nielson et al., 1996; Heitner and Dickson, 1997). According to the 
present data, insulin dramatically reduces intracellular levels of $\mathrm{A} \beta 40 / 42$ and increases $\mathrm{A} \beta 40 / 42$ secretion in neuroblastoma cells and primary neuronal cultures by promoting $\beta$ APP trafficking via a known insulin-signaling pathway, suggesting that the insulin/ IGF-1 pathway may play a role in AD pathogenesis. However, future studies must assess whether diabetes contributes to AD and, if so, whether such effects are mediated via the action of insulin on $\beta \mathrm{APP} / \mathrm{A} \beta$ metabolism.

\section{REFERENCES}

Abbott M-A, Wells DG, Fallon JR (1999) The insulin receptor tyrosine kinase substrate p58/53 and the insulin receptor are components of CNS synapses. J Neurosci 19:7300-7308.

Alessi DR, Cuenda A, Cohen P, Dudley DT, Saltiel AR (1995) PD 098059 is a specific inhibitor of the activation of mitogen-activated protein kinase kinase in vitro and in vivo. J Biol Chem 270:27489-27494.

Barr VA, Malide D, Zarnowski M, Taylor SI, Cushman SW (1997) Insulin stimulates both leptin secretion and production by rat white adipose tissue. Endocrinology 138:4463-4472.

Bogan JS, Lodish HF (1999) Two compartments for insulin-stimulated exocytosis in 3T3-L1 adipocytes defined by endogenous ACRP30 and GLUT4. J Cell Biol 146:609-620.

Buxbaum JD, Gandy SE, Cicchetti P, Ehrlich ME, Czernik AJ, Fracasso RP, Ramabhadram TV, Uterbeck AJ, Greengard P (1990) Processing of Alzheimer $\beta / \mathrm{A} 4$ amyloid precursor protein: modulation by agents that regulate protein phosphorylation. Proc Natl Acad Sci USA 87:6003-6006.

Chui DH, Tanahashi H, Gallyas F, Tabira T (1999) Transgenic mice with Alzheimer presenilin-1 accelerated neurodegeneration without amyloid plaque formation. Nat Med 5:560-564.

Cook DG, Forman MS, Sung JC, Leight S, Kolson DL, Iwatsubo T, Lee VM-Y, Doms RW (1997) Alzheimer's $A \beta_{1-42}$ is generated in the endoplasmic reticulum/intermediate compartment of NT2N cells. Nat Med 3:1021-1023.

Craft S, Peskind E, Schwartz MW, Schellenberg GD, Raskind M, Porte Jr D (1998) Cerebrospinal fluid and plasma insulin levels in Alzheimer's disease. Neurology 50:164-168.

Craft S, Asthana S, Schellenberg G, Cherrier M, Baker LD, Newcomer J, Plymate S, Latendresse S, Petrova A, Raskind M, Peskind E, Lofgreen C, Grimwood K (1999) Insulin metabolism in Alzheimer's disease differs according to apolipoprotein E genotype and gender. Neuroendocrinology 70:146-152.

Dudley DT, Pang L, Decker SJ, Bridges AJ, Saltiel AR (1995) A synthetic inhibitor of the mitogen-activated protein kinase cascade. Proc Natl Acad Sci USA 92:7686-7689.

Frolich L, Blum-Degen D, Bernstein H-G, Engelsberger S, Humrich J, Laufer S, Muschner D, Thalheimer A, Turk A, Hoyer S, Zochling R, Boissl KW, Jellinger K, Riederer P (1998) Brain insulin and insulin receptors in aging and sporadic Alzheimer's disease. J Neural Transm 105:423-438.

Frolich L, Blum-Degen D, Riederer P, Hoyer S (1999) A disturbance in the neuronal insulin receptor signal transduction in sporadic Alzheimer's disease. Ann NY Acad Sci 893:290-293.

Gouras GK, Xu H, Jovanovic JN, Buxbaum JD, Wang R, Greengard P, Relkin NR, Gandy S (1998) Generation and regulation of $\beta$-amyloid peptide variants by neurons. J Neurochem 71:1920-1925.

Gouras GK, Tsai J, Naslund J, Vincent B, Edgar M, Greenfield JP, Haroutunian V, Buxbaum JD, Xu H, Greengard P, Relkin NR (2000) Intraneuronal $\mathrm{A} \beta 42$ accumulation in human brain. Am J Pathol 156:15-20.

Greenfield JP, Tsai J, Gouras GK, Hai B, Thinakaran G, Checler F, Sisodia SS, Greengard P, Xu H (1999) Endoplasmic reticulum and trans-Golgi network generate distinct populations of Alzheimer $\beta$-amyloid peptides. Proc Natl Acad Sci USA 96:742-747.

Hartmann T, Bieger SC, Bruhl B, Tienari PJ, Ida N, Allsop D, Roberts GW, Masters CL, Dotti CG, Unsicker K, Beyreuther K (1997) Distinct sites of intracellular production for Alzheimer's disease A $\beta 40 / 42$ amyloid peptides. Nat Med 3:1016-1020.

Heitner J, Dickson D (1997) Diabetics do not have increased Alzheimertype pathology compared with age-matched control subjects. A retrospective postmortem immunocytochemical and histofluorescent study. Neurology 49:1306-1311.

Hong M, Lee VM-Y (1997) Insulin and insulin-like growth factor-1 regulate tau phosphorylation in cultured human neurons. J Biol Chem 272:19547-19553.

Iwata N, Tsubuki S, Takaki Y, Watanabe K, Sekiguchi M, Hosoki E, Kawashima-Morishima M, Lee H-J, Hama E, Sekine-Aizawa Y, Saido TC (2000) Identification of the major A $\beta 1$-42-degrading catabolic pathway in brain parenchyma: suppression leads to biochemical and pathological deposition. Nat Med 6:143-150.
Lamberts SW, van den Beld AW, van der Lely AJ (1997) The endocrinology of aging. Science 278:419-424.

Landin K, Blennow K, Wallin A, Gottfries CG (1993) Low blood pressure and blood glucose levels in Alzheimer's disease. Evidence for a hypometabolic disorder? J Intern Med 233:357-363.

Lee S-J, Liyanage U, Bickel PE, Xia W, Lansbury PT, Kosik KS (1998) A detergent-insoluble membrane compartment contains $A \beta$ in vivo. Nat Med 4:730-734.

Leibson CL, Rocca WA, Hanson VA, Cha R, Kokmen E, O'Brien PC, Palumbo PJ (1997) The risk of dementia among persons with diabetes mellitus: a population-based cohort study. Am J Epidemiol 145:301-308.

Lesort M, Johnson GVW (2000) Insulin-like growth factor-1 and insulin mediate transient site-selective increases in tau phosphorylation in primary cortical neurons. Neuroscience 99:305-316.

Lesort M, Jope RS, Johnson GVW (1999) Insulin transiently increases tau phosphorylation: involvement of glycogen synthase kinase-3 $\beta$ and Fyn tyrosine kinase. J Neurochem 72:576-584.

Lopaczynski W (1999) Differential regulation of signaling pathways for insulin and insulin-like growth factor-1. Acta Biochim Pol 46:51-60.

Lovestone S (1999) Diabetes and dementia. Neurology 53:1907-1909.

Mills J, Reiner PB (1999) Regulation of amyloid precursor protein cleavage. J Neurochem 72:443-460.

Mochizuki A, Tamaoka A, Shimoata A, Komatsuzaki Y, Shoji S (2000) A $\beta 42$-positive non-pyramidal neurons around amyloid plaques in Alzheimer's disease. Lancet 355:42-43.

Mortel KF, Wood S, Pavol MA, Meyer JS, Rexer JL (1993) Analysis of familial and individual risk factors among patients with ischemic vascular dementia and Alzheimer's disease. Angiology 44:599-605.

Nielson KA, Nolan JH, Berchtold NC, Sandman CA, Mulnard RA, Cotman CW (1996) Apolipoprotein-E genotyping of diabetic dementia patients: is diabetes rare in Alzheimer's disease? J Am Geriatr Soc 44:897-904.

Ott A, Stolk RP, Hofman A, van Harskemp F, Grobbee DE, Breteler MMB (1996) Association of diabetes mellitus and the risk of dementia. Diabetologia 39:1392-1397.

Ott A, Stolk RP, van Harskamp F, Pols HAP, Hofman A, Breteler MMB (1999) Diabetes mellitus and the risk of dementia. The Rotterdam study. Neurology 53:1937-1942.

Perry HM (1999) The endocrinology of aging. Clin Chem 45:1369-1376.

Pessin JE, Thurmond DC, Elmendorf JS, Coker KJ, Okada S (1999) Molecular basis of insulin-stimulated GLUT4 vesicle trafficking. Location! Location! Location! J Biol Chem 274:2593-2596.

Qiu WQ, Walsh DM, Ye Z, Vekrellis K, Zhang J, Podlisny MB, Rosner RM, Safavi A, Hersh LB, Selkoe DJ (1998) Insulin-degrading enzyme regulates extracellular levels of amyloid $\beta$-protein by degradation. J Biol Chem 273:32730-32738.

Refolo LM, Salton SRJ, Anderson JP, Mehta P, Robakis NK (1989) Nerve and epidermal growth factors induce the release of the Alzheimer amyloid precursor from PC12 cell cultures. Biochem Biophys Res Commun 164:664-670.

Schubert D, Jin L-W, Saitoh T, Cole G (1989) The regulation of amyloid $\beta$-protein precursor secretion and its modulatory role in cell adhesion. Neuron 3:689-694.

Seeger M, Norstedt C, Petacenska S, Kovacs DM, Gouras GK, Hahne S, Fraser P, Levesque L, Czernik AJ, St. George-Hyslop P, Sisodia SS, Thinakaran G, Tanzi RE, Greengard P, Gandy S (1997) Evidence for phosphorylation and oligomeric assembly of presenilin1. Proc Natl Acad Sci USA 94:5090-5094.

Selkoe DJ (1998) The cell biology of $\beta$-amyloid precursor protein and presenilin in Alzheimer's disease. Trends Cell Biol 8:447-453.

Shii K, Roth RA (1986) Inhibition of insulin degradation by hepatoma cells after microinjection of monoclonal antibodies to a specific cytosolic protease. Proc Natl Acad Sci USA 83:4147-4151.

Skovronsky DM, Doms RW, Lee VM-Y (1998) Detection of intraneuronal pool of insoluble amyloid $\beta$-protein that accumulates with time in culture. J Biol Chem 141:1031-1039.

Solano DC, Sironi M, Bonfini C, Solerte B, Govoni S, Racchi M (2000) Insulin regulates amyloid precursor protein release via phosphatidyl inositol 3 kinase-dependent pathway. FASEB J 14:1015-1022.

Vekrellis K, Ye Z, Qiu WQ, Walsh DM, Hartley D, Chesneau V, Rosner RM, Selkoe DJ (2000) Neurons regulate extracellular levels of amyloid $\beta$-protein via proteolysis by insulin-degrading enzyme. J Neurosci 20:1657-1665.

Wan Q, Xiong ZG, Man HY, Ackerley CA, Braunton J, Lu WY, Becker LE, MacDonald JF, Wang YT (1997) Recruitment of functional $\mathrm{GABA}_{\mathrm{A}}$ receptors to postsynaptic domains by insulin. Nature 388:686-690.

Werther GA, Hogg A, Oldfield BJ, McKinley MJ, Figdor R, Allen AM, Mendelsohn FA (1987) Localization and characterization of insulin receptors in rat brain and pituitary gland using in vitro autoradiography and computerized densitometry. Endocrinology 121:1562-1570.

Wickelgren I (1998) Tracking insulin to the mind. Science 280:517-519. 
Wild-Bode C, Yamazaki T, Capell A, Leimer U, Steiner H, Ihara Y, Haass C (1997) Intracellular generation and accumulation of amyloid $\beta$-peptide terminating at amino acid 42. J Biol Chem 272:16085-16088.

Wilson CA, Doms RW, Lee VM-Y (1999) Intracellular APP processing and $\mathrm{A} \beta$ production in Alzheimer disease. J Neuropathol Exp Neurol 58:787-794.

Xu H, Sweeney D, Wang R, Thinakaran G, Lo AC, Sisodia SS, Greengard P, Gandy S (1997) Generation of Alzheimer $\beta$-amyloid protein in the trans-Golgi network in the apparent absence of vesicle formation. Proc Natl Acad Sci USA 94:3748-3752.

Xu H, Gouras GK, Greenfield JP, Vincent B, Naslund J, Mazzarelli L, Fried G, Jovanovic JN, Seeger M, Relkin NR, Liao F, Checler F,
Buxbaum JD, Charr BT, Thinakaran G, Sisodia SS, Wang R, Greengard P, Gandy S (1998) Estrogen reduces neuronal generation of Alzheimer $\beta$-amyloid peptides. Nat Med 4:447-451.

Yoshitake T, Kiyoara Y, Kato I, Ohmura T, Iwamoto H, Nakayama K, Ohmori S, Nomiyama K, Kawano K, Ueda K (1995) Incidence and risk factors of vascular dementia and Alzheimer's disease in a defined elderly Japanese population: the Hisayama study. Neurology 45:1161-1168.

Zhao W, Chen H, Xu H, Moore E, Meiri N, Quon MJ, Alkon DJ (1999) Brain insulin receptors and spatial memory. Correlated changes in gene expression, tyrosine phosphorylation, and signaling molecules in the hippocampus of water maze trained rats. J Biol Chem 274:34893-34902. 